\title{
Correction to: Development and psychometric properties of the problematic mobile video gaming scale
}

\section{Jia-Rong Sheng ${ }^{1} \cdot$ Jin-Liang Wang ${ }^{1}$}

Published online: 30 August 2019

(C) Springer Science+Business Media, LLC, part of Springer Nature 2019

\section{Correction: Curr Psychol https://doi.org/10.1007/s12144-019-00415-6}

The article Development and psychometric properties of the problematic mobile video gaming scale, written by JiaRong Sheng and Jin-Liang Wang, was originally published electronically on the publisher's internet portal (currently SpringerLink) on 13 August 2019 with open access. With the author(s)' decision to step back from Open Choice, the copyright of the article changed on August 2019 to (C) Springer Science+Business Media, LLC, part of Springer Nature 2019 and the article is forthwith distributed under the terms of copyright.

The original article has been corrected.

Publisher's note Springer Nature remains neutral with regard to jurisdictional claims in published maps and institutional affiliations. 